\title{
Engaging with the politics of downward rescaling: representing women in regional development policymaking in Québec (Canada)
}

\author{
Dominique Masson
}

Published online: 9 January 2007

C) Springer Science+Business Media B.V. 2007

\section{Erratum to: GeoJournal DOI 10.1007/s10708-006-0025-x}

With reference to the missing abstract and keywords

The correct text should read:

\begin{abstract}
Searching for new spatial "fixes" to better fit the new conditions of economic, social and political regulation in a context of globalization states have, over the past decades, rescaled upward, downward, and outward activities and responsibilities that were formerly the domain and privilege of national governments. These transformations raise a series of questions for feminist scholarship. A central one certainly is: how are such changes in the places and scales of public policy processes affecting the capacity of women's movements and other feminist actors to pursue gender inclusive public policy? This article contributes to such an inquiry by drawing on the recent re-territorialization of Regional Develop-
\end{abstract}

The online version of the original article can be found at http://dx.doi.org/10.1007/s10708-006-0025-x

D. Masson $(\square)$

Institute of Women's Studies, University of Ottawa,

143 Séraphin-Marion, Ottawa, Ontario,

Canada K1N 6N5

e-mail: dmasson@uottawa.ca ment policy in Québec (Canada) to explore issues related to the downward rescaling of state spaces to the regional scale, the associated shift from government to governance, and the capacity of women's movement actors to act productively within rescaled political contexts. It focuses on the nature of the politics of presence and of the politics of interests favored by women's movement actors in their attempts to influence public policy in the new Regional Development Councils put in place by the regionalizing reform of 1992. Tensions and challenges posed to women's organizing are highlighted. The article concludes on the difference that modes of governance, the dominance of neoliberal discourses, and the scale of the region make for the fate of women's movement actors trying to influence policymaking in downscaled policy processes.

Keywords Devolution to regions - Québec (Canada) - Regional development policy . Rescaling of politics - Women's movement . Women's representation 